\title{
Quantitative Parameters of Interdental Gingiva in Chronic Periodontitis Patients with IFN- $\gamma$ Gene Polymorphism
}

\author{
Nadia Sheibak ${ }^{1}$, Zahra Heidari ${ }^{1,2}$, Hamidreza Mahmoudzadeh-Sagheb ${ }^{1,2}$ \\ ${ }^{1}$ Department of Histology, School of Medicine, Zahedan University of Medical \\ Sciences, Zahedan, Iran; \\ ${ }^{2}$ Infectious Diseases and Tropical Medicine Research Center, Zahedan University \\ of Medical Sciences, Zahedan, Iran \\ Received November 1, 2016; Accepted March 9, 2017.
}

Key words: Chronic periodontitis - Interferon-gamma - Genetic Polymorphism - Gingiva

\begin{abstract}
Chronic periodontitis (CP), an infectious disease resulting in inflammation within the periodontal tissue, is the main cause of adult tooth loss. $\mathrm{CP}$ is a multi-factorial disorder and the interaction between multiple genetic and environmental factors results in the manifestation of this disease. Recent researches in periodontitis has focused on cytokine gene polymorphisms that play important role in periodontal inflammation, but few studies investigated histological change that occur during $\mathrm{CP}$ in the supporting tissue of teeth. The aims of this study were to investigate the association of IFN- $\gamma+874 \mathrm{~A} / \mathrm{T}$ polymorphisms and quantitative parameters of interdental gingiva in $\mathrm{CP}$ patients. The study samples were interdental gingiva biopsies from 60 individuals including 38 patients and 22 healthy subjects. After determination of IFN $-\gamma+874 \mathrm{~A} / \mathrm{T}$ gene polymorphism by amplification refractory mutation system-polymerase chain reaction (ARMSPCR), patients were divided in three subgroups: 10 AA, 18 AT and 10 TT. After slides preparation, quantitative parameters were estimated by Cavalieri's pointcounting method. Statistical analyses were performed using Mann-Whitney and Kruskal-Wallis test to compare differences between groups. The volume density $(\mathrm{Vv})$ of epithelium, connective tissue and its components were significantly different between the control and CP groups $(P<0.05)$. Statistically significant differences in the $\mathrm{Vv}$ of collagenous and non-collagenous matrix of interdental gingiva between
\end{abstract}

Mailing Address: Prof. Zahra Heidari, PhD., Department of Histology, School of Medicine, Zahedan University of Medical Sciences, Zahedan, Iran; Phone: 98-543 32957 94; Fax: 98-543 32957 94; e-mail: histology_iri@yahoo.com 
AA, AT and TT groups were found $(P<0.05)$. Result of present study shows that IFN $-\gamma+874 \mathrm{~A} / \mathrm{T}$ is strongly associated with some quantitative parameters of connective tissue constituents of interdental papilla in CP patients.

\section{Introduction}

Periodontal diseases affect millions of people around the world and up to $90 \%$ of the global population may be affected by some forms of milder periodontal diseases, including gingivitis (Kim and Amar, 2006; Erciyas et al., 2010). In around $10-15 \%$ of these high-risk groups, the disease can quickly progress from chronic gingivitis to severe destructive periodontitis (Holla et al., 2011).

Chronic periodontitis (CP), as we know it today, is a complex disease associated with a chronic oral bacterial infection that results in periodontal inflammation (Di Benedetto et al., 2013; Heidari, 2014). Periodontitis has been defined as progressive destruction of supporting tissues of the teeth that may lead to tooth loss (Preethi et al., 2014).

Periodontitis is characterized by a chronic infection associated with Gramnegative anaerobic bacteria in the dental biofilm (Holla et al., 2011). Mechanisms of damage to the dental supportive structures include direct tissue damage as a result of bacterial plaque, and indirect damage due to bacterial effects on the immune system and the host inflammatory response (Armingohar et al., 2014). The disease may be described by the severity of disease as mild, moderate or severe based on the amount of clinical attachment loss of gingiva (Armitage, 2004).

$\mathrm{CP}$ is a multifactorial disease affected by numerous risk factors such as smoking, social background, diabetes, genetic susceptibility, attitude towards health, and supragingival plaque control. Such risk factors influence the susceptibility to extent, severity and course of the disease (Stabholz et al., 2010; Genco and Borgnakke, 2013). It may be assumed that, the interactions between various clusters of modifying genes and environment are responsible for the susceptibility to $\mathrm{CP}$ (Laine et al., 2012; Heidari, 2014). To date, genetic determinants for CP patient have not been described clearly. A genetic predisposition to progressive destruction of periodontal tissues in response to bacterial plaque may exist. Researchers have a long suspicion that the prevalence of periodontitis vary among different racial and ethnic groups (Loos et al., 2005; Heidari et al., 2013). Recently researches on periodontitis pathogenesis have focused on cytokines gene polymorphisms (Irwin and Myrillas, 1998; Erciyas et al., 2010).

Cytokines are inflammatory mediators that have an important role in host defence and regulation of the immune system (Okada and Murakami, 1998; Atilla et al., 2006).

IFN- $\gamma$ is an immune regulatory cytokine and has been found in infected human periodontium. Its level can be associated with progression of lesions and severity of inflammatory diseases. This cytokine acts against viruses, tumours and it is able to activate macrophages (Zhang et al., 2010; Holla et al., 2011; Tanaka et al., 2012). Reports showed that IFN- $\gamma$ carrier cells, such as Th1 have a strong association 
with the destructive process during periodontitis (César-Neto et al., 2006). Genetic studies of periodontal disease mainly focused on the potentially functional polymorphisms of IFN- $\gamma$ like +874 A/T (Erciyas et al., 2010; Holla et al., 2011). According to reports, IFN- $\gamma+874 \mathrm{~A} / \mathrm{T}$ genetic polymorphism is responsible for different expression levels of IFN- $\gamma$ and it is able to impress severity and length of immune response during inflammatory diseases (Pravica et al., 2000; Pacheco et al., 2008; Holla et al., 2011; Liu et al., 2015).

The aim of the present study was investigation of association between IFN- $\gamma$ $+874 \mathrm{~A} / \mathrm{T}$ gene polymorphism and quantitative parameters of interdental gingiva in CP patients.

\section{Material and Methods}

The present study is a complementary investigation to our previous study. Our previous research included $210 \mathrm{CP}$ patients, and 100 healthy controls and studied IFN- $\gamma+874 \mathrm{~A} / \mathrm{T}$ genetic polymorphism association with susceptibility to $\mathrm{CP}$ (Heidari et al., 2015a).

Patient selection was done according to the criteria that defined by the International Workshop for Classification of Periodontal Diseases and Conditions (Armitage, 1999, 2004). The procedures followed in accordance with the ethical standards of the University Ethics Committee on human experimentation and obtained written informed consent from the participants. Patients and controls characteristics and selection criteria were listed in our previous studies on CP (Heidari et al., 2014a, b).

$38 \mathrm{CP}$ patients and 22 healthy subjects were selected for the present study. These individuals were selected from samples of our previous investigation. Briefly, CP patients were selected from individuals with general health that had at least 20 teeth for probing. The disease was diagnosed by physical examination, determination of probing depth and clinical attachment loss, bleeding during probing and radiography of alveolar bone (if necessary). Periodontitis cases were defined as individuals who had at least three tooth sites with clinical attachment loss greater than or equal to $4 \mathrm{~mm}$, and at least two sites with pocket depth greater than or equal to $3 \mathrm{~mm}$, as was described by Armitage (2004) and Kim and Amar (2006).

Control subjects were selected from individuals with confirmed periodontal health that refer to Dentistry Clinic for other reasons and were similar to the patient group in terms of ethnicity and gender.

Exclusion criteria included smoking, pregnancy, systemic diseases such as diabetes mellitus, HIV infection and inflammatory conditions and also the use of antiinflammatory drugs as were noted in our previous studies (Heidari et al., 2014a, b).

Case selection was based on IFN- $\gamma+874 \mathrm{~A} / \mathrm{T}$ genotypes that were determined by the amplification refractory mutation system-polymerase chain reaction (ARMSPCR) previously (Heidari et al., 2015a). 
Table 1 - Demographic parameters of chronic periodontitis patients and control group

\begin{tabular}{lccc}
\hline & Chronic periodontitis $(\mathrm{n}=38)$ & Control $(\mathrm{n}=22)$ & P-value \\
\hline Age (year) & $33.73 \pm 1.02 *$ & $35.36 \pm 1.27^{*}$ & 0.114 \\
\hline Gender $(\%)$ & & & 0.553 \\
\hline Female & $\mathrm{n}=23(60.50 \%)$ & $\mathrm{n}=15(68.20 \%)$ & \\
Male & $\mathrm{n}=15(39.50 \%)$ & $\mathrm{n}=7 \quad(31.80 \%)$ & \\
\hline
\end{tabular}

*the values were presented as mean \pm standard deviation (SD)

The average age of patient individuals was $33.73 \pm 1.02$ ( 23 females and 15 males) and healthy individuals included 15 females and 7 males (35.36 \pm 1.27$)$. Age, gender and ethnicity among patients and controls were matched (Table 1). The average age of patients results from regional health indicators and poor oral hygiene that caused the prevalence of disease in young adults.

The present study was performed on interdental gingiva tissue samples that were obtained during gingival surgical operations in the treatment process of subjects. Thirty-eight tissue samples from CP patients based on detected genotypes were divided into three case groups (10 TT, 18 AT, and $10 \mathrm{AA}$ ).

Control gingival samples $(n=22)$ were acquired from healthy individuals during orthodontic or prosthodontics treatments. Preparation procedure of tissue samples, including fixation and embedding have been described previously (Heidari et al., 2014a).

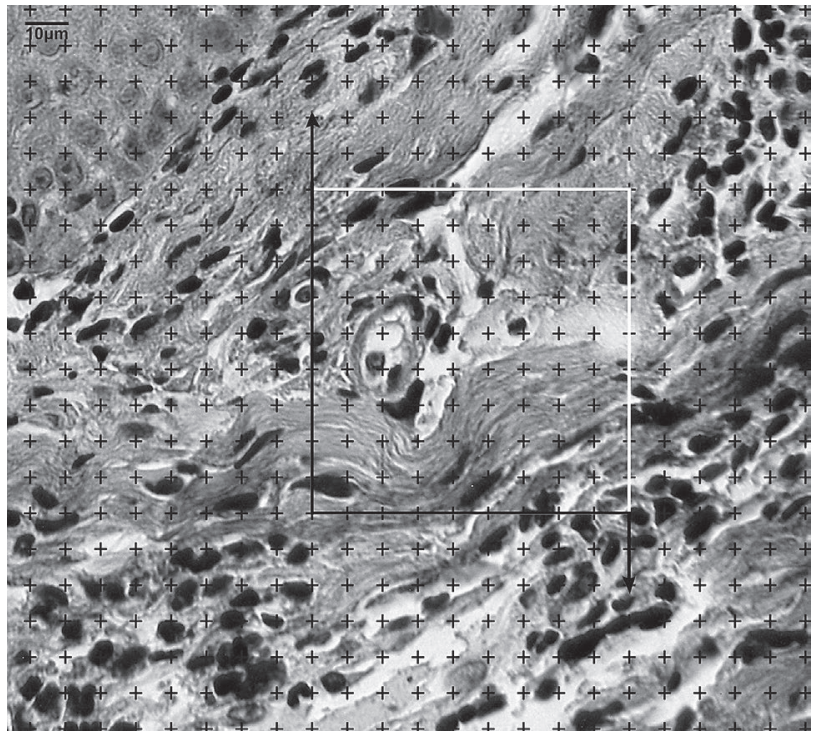

Figure 1 - Sample of a selected field for estimation the quantitative parameters of interdental gingiva using stereological grid of points and Cavalieri's principle (original magnification $400 \times$, scale bar $=$ $10 \mu \mathrm{m})$.

Sheibak N.; Heidari Z.; Mahmoudzadeh-Sagheb H. 
After embedding tissues in paraffin blocks, $4 \mu \mathrm{m}$-thick sections were prepared by a microtome. Sections with intervals of $200 \mu \mathrm{m}$ were selected from each tissue block (10 to 13 sections from each block) by systematic, uniform random sampling (SURS) as were described previously (Heidari et al., 2014a, b). Selected sections were stained by Masson trichrome staining method (Heidari et al., 2014a).

Up to 15 fields were selected under a photomicroscope by movement of stage in $X$ and $Y$ directions by SURS (magnification 400x) on each section. An estimate of the volume density $(\mathrm{Vv})$ of the components was calculated using a superimposed test system of points on these fields. A stereological grid containing square-shaped field $(80 \times 80 \mu \mathrm{m})$, which included 81 test points was used for this estimation. Points encountered the various components of the tissue were counted. In the counting frame, all the profiles trapped completely inside the frame, and the profiles hit by the inclusion edge (white lines) must be counted. However, any profile hitting the exclusion edges and their extension (black lines) must be excluded from counting (Figure 1). Quantitative parameters of interdental gingiva including volume density of gingival epithelium, connective tissue proper, components of connective tissue proper comprising collagenous matrix, non-collagenous matrix and blood vessels were estimated in both groups using Cavalieri's principle. Comparative volume density of tissue components was gained using the formula:

$$
V_{v}=\frac{\sum P_{\text {part }}}{\sum P_{\text {total }}}
$$

$P_{\text {part }}$ is the number of test points falling in all structure profiles of desired part of the tissue (for example collagenous matrix) and $P_{\text {total }}$ is the number of points that hit to all gingival tissue (Figure 1). All stereological analyses were done on maskcoded slides. Coefficient errors were checked and were less than $5 \%$. All details of this method were explained previously in our previous studies (Heidari et al., 2014a, b).

Data are presented as mean \pm SEM (standard error of mean) for each parameter investigated. Differences were compared between patient and control groups using Mann-Whitney $\mathrm{U}$ test. Kruskal-Wallis $\mathrm{H}$ test was used to compare differences between three groups with different genotypes of IFN- $\gamma+874 \mathrm{~A} / \mathrm{T}$ gene polymorphism. The significant level was set to $\mathrm{P}<0.05$. All statistical analyses were performed by employing SPSS software (ver. 16).

\section{Results}

Demographic parameters of CP subjects and healthy controls were shown in Table 1.

Stereological analysis of quantitative parameters showed that the volume density $(\mathrm{Vv})$ of epithelium (epithelium volume/gingival tissue volume ratio), connective tissue proper of gingival tissue, and also collagenous and non-collagenous 
Table 2 - Quantitative parameters of interdental gingiva in patients with chronic periodontitis and healthy controls

\begin{tabular}{lccc}
\hline Volume density $(\%)$ & $\begin{array}{c}\text { CP group }(n=38) \\
(\text { mean } \pm \text { SEM)* }\end{array}$ & $\begin{array}{c}\text { Control group }(n=22) \\
(\text { mean } \pm \text { SEM)* }\end{array}$ & P-value \\
\hline Epithelium/gingival tissue & $42.16 \pm 1.528$ & $35.89 \pm 2.314$ & $0.048^{* *}$ \\
Connective tissue/gingival tissue & $57.84 \pm 1.535$ & $64.08 \pm 2.315$ & $0.048^{* *}$ \\
Collagenous matrix/CT & $34.94 \pm 0.886$ & $46.93 \pm 1.137$ & $<0.0001^{* *}$ \\
Non-collagenous matrix/CT & $62.89 \pm 0.879$ & $52.04 \pm 1.096$ & $<0.0001^{* *}$ \\
Blood vessels/CT & $2.10 \pm 0.121$ & $0.98 \pm 0.159$ & $<0.0001^{* *}$ \\
\hline
\end{tabular}

*the values are presented as mean \pm standard error of mean $(S E M)$; **significant difference between groups $(P<0.05)$; $\mathrm{CT}$ - connective tissue proper; $\mathrm{CP}$ - chronic periodontitis

70
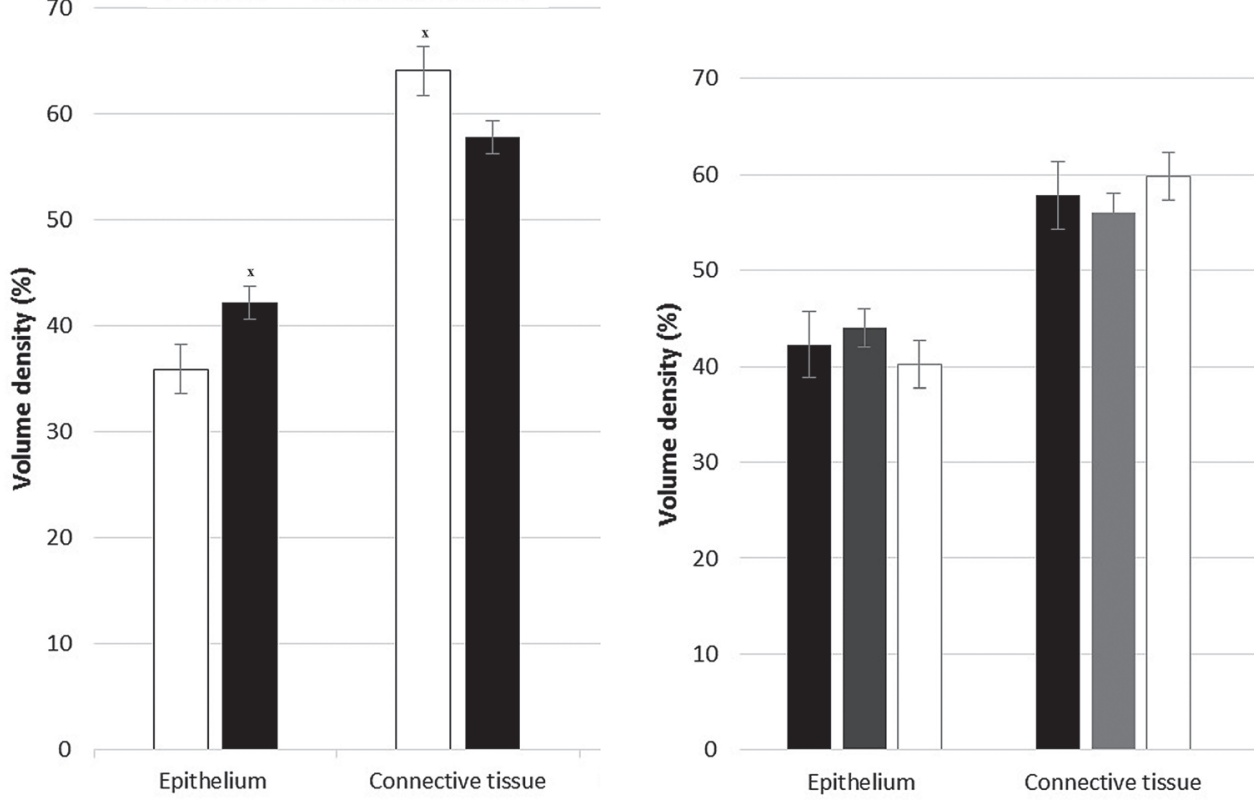

Figure 2 - Stereological comparison of interdental gingiva components in patients with chronic periodontitis and healthy controls ( $x$ - significant difference).

matrixes and blood vessels of connective tissue proper had statistically significant differences between CP patients and controls $(\mathrm{P}<0.05)$ (Table 2 and Figure 2). $\mathrm{V} v$ of collagenous and non-collagenous matrix differ significantly between $C P$ patients with AA, AT and TT genotypes of IFN- $\gamma+874 \mathrm{~A} / \mathrm{T}$ gene polymorphism $(\mathrm{P}<0.05)$ (Table 3 and Figure 3). 


\section{Table 3 - Quantitative parameters of interdental gingiva in patients with chronic periodontitis and IFN- $\gamma+874 \mathrm{~A} / \mathrm{T}$ gene polymorphism (AA, AT and TT genotypes)}

\begin{tabular}{lcccc}
\hline Volume density (\%) & \multicolumn{3}{c}{ Genotypes } & P-value \\
\cline { 2 - 4 } & $\begin{array}{c}\text { AA }(n=10) \\
(\text { mean } \pm \text { SEM)* }\end{array}$ & $\begin{array}{c}\text { AT }(n=18) \\
(\text { mean } \pm \text { SEM)* }\end{array}$ & $\begin{array}{c}\text { TT }(n=10) \\
(\text { mean } \pm \text { SEM)* }\end{array}$ & \\
\hline $\begin{array}{l}\text { Epithelium/gingival tissue } \\
\text { Connective tissue/ }\end{array}$ & $42.27 \pm 3.447$ & $43.99 \pm 1.948$ & $40.22 \pm 2.472$ & NS \\
$\begin{array}{l}\text { gingival tissue } \\
\begin{array}{l}\text { Collagenous matrix/CT } \\
\text { Non-collagenous }\end{array}\end{array}$ & $36.78 \pm 3.476$ & $55.99 \pm 1.948$ & $59.76 \pm 2.471$ & NS \\
$\begin{array}{l}\text { matrix/CT } \\
\text { Blood vessels/CT }\end{array}$ & $60.61 \pm 1.666$ & $32.52 \pm 1.224$ & $37.46 \pm 1.468$ & $0.027^{* *}$ \\
& $2.56 \pm 0.291$ & $65.48 \pm 1.202$ & $60.50 \pm 1.548$ & $0.029 * *$ \\
\end{tabular}

*the values are presented as mean \pm standard error of mean (SEM); ${ }^{* *}$ significant difference between three genotypes $(\mathrm{P}<0.05)$; NS - not significant $(\mathrm{P}>0.05)$; $\mathrm{CT}$ - connective tissue proper

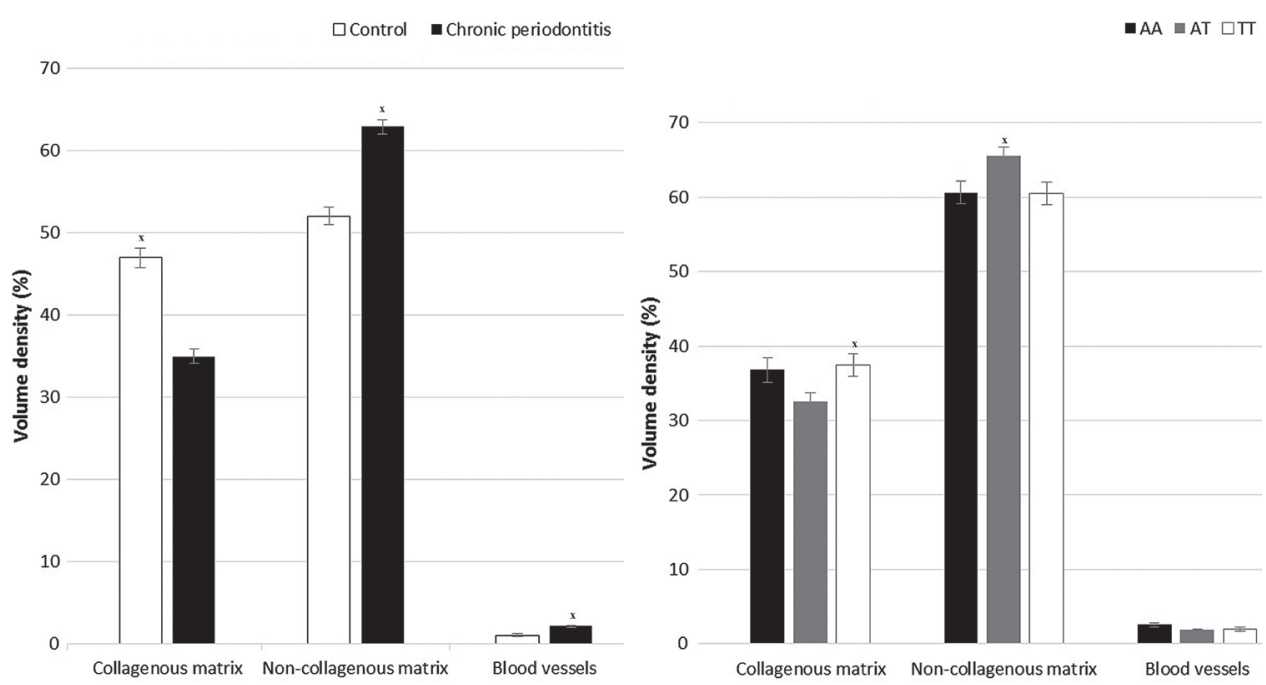

Figure 3 - Quantitative parameters of interdental gingiva in patients with chronic periodontitis and IFN- $\gamma$ +874 A/T gene polymorphism (AA, AT and TT genotypes) ( $x$ - significant difference).

\section{Discussion}

The present study showed that quantitative parameters of interdental gingiva including volume of epithelium, connective tissue, blood vessels and collagenous and non-collagenous matrixes had statistically significant differences in CP patients compared with healthy controls. We also found that gingival collagenous and noncollagenous matrixes $V v$ were significantly different between the patients with different IFN- $\gamma+874 \mathrm{~A} / \mathrm{T}$ gene polymorphism. 
Reports showed that histological changes of gingival epithelium during periodontal inflammation were caused by edema and increase of volume (Séguier et al., 2000b; Heidari et al., 2014a). Increasing in Vv of patient's gingival epithelium may be caused by infiltration of inflammatory cells too, as we observed in our sample sections (Younes et al., 2009; Heidari et al., 2014a). Our findings showed that there was a significant increase in epithelium $\mathrm{V} v$ in $\mathrm{CP}$ samples compared with healthy tissues. Therefore, accumulation of immune cells in epithelium and increased volume of epithelial cells in response to inflammation process probably have been the reason of elevated epithelium $\mathrm{Vv}$ in patients.

Different histological changes were found in gingival connective tissue, including an elevated number of inflammatory lesions, collagen fiber fragmentation and decrease in fibroblast population (Séguier et al., 2000a; Golijanin et al., 2015). Our results showed that $\mathrm{Vv}$ of connective tissue in patient's gingiva were significantly lower than in control samples. Our previous stereological studies on CP samples confirmed this finding (Heidari et al., 2014a, b). In basis of previous reports, periodontal inflammation was associated with degeneration of extracellular matrix that caused the connective tissue loss (Heidari, 2014; Golijanin et al., 2015).

The main macromolecules of the gingival extracellular matrix are collagen fibers that have important role in the integrity of teeth supporting tissues (Ohlrich et al., 2009; Heidari et al., 2014a). Reports have suggested that the decrease in density of collagen fibers might reflect the disease severity (Heidari et al., 2014a; Golijanin et al., 2015). Our results showed a significant decrease of $\mathrm{Vv}$ gingival collagenous matrix in the samples from patients in comparison with the control group. Apply of stereological methods demonstrated that there was a gradual loss of fibroblast population of gingival connective tissue and this decrease was related to significant loss of collagen fibers in the severe periodontitis tissue samples (Séguier et al., 2000a; Golijanin et al., 2015).

The gamut of inflammatory fields was associated quantitative and qualitative changes of collagenous matrix (Golijanin et al., 2015). We observed qualitatively that many inflammatory lesions occurred in the connective tissue of CP gingival samples. According to our findings, the volume of non-collagenous matrix in the $C P$ group compared with healthy subjects showed a significant elevation. Pinchback et al. (1996) found that during periodontal inflammation a replacement of connective tissue fibers with numerous inflammatory cells beneath the gingival epithelium occurs. Accumulation of inflammatory cells in connective tissue is probably the cause of elevated volume of non-collagenous matrix, which corresponds with our findings (Okada and Murakami, 1998; Younes et al., 2009). Due to some technical limitations in our department, we did not work on the cell counting. We suggest further studies in this field.

Chapple et al. (2000) found that vascular expansion in periodontal pocket was related to CP progression and the thickened basement membrane of capillaries and venules represented an evidence of angiogenic activity during inflammation. 
Vascular response to inflammation includes angiogenesis and capillaries dilation (Pinchback et al., 1996; Chapple et al., 2000; Zoellner et al., 2002). The present study demonstrated that $\mathrm{Vv}$ of blood vessels in $\mathrm{CP}$ gingival tissues was significantly higher than that of healthy subjects. Increased number and diameter of blood vessels is probably an effective change that supplies infiltration of plasma immune agents toward inflammatory lesions, where they can regulate tissue destruction.

Until now, we could not find any data concerning the quantitative parameters of gingival tissues of individuals with IFN- $\gamma+874 \mathrm{~A} / \mathrm{T}$ gene polymorphism. This study appears to be the first of its kind reporting the IFN- $\gamma+874 \mathrm{~A} / \mathrm{T}$ gene polymorphism and quantitative histological changes in gingival tissues that may lead to tooth loss.

We have already done some investigations on association of other cytokine gene polymorphisms with susceptibility to $\mathrm{CP}$ and quantitative histological changes that occurred during this infection (Heidari et al., 2013, 2014a, b).

Our present results showed that there was no significant difference in epithelium and connective tissue volume between CP samples with TT, AT and AA genotypes. In line with these results, we did not find any significant differences in epithelium and connective tissue $V v$ between different genotypes of TGF- $\beta-509 \mathrm{C} / \mathrm{T}$ and $29 \mathrm{C} / \mathrm{T}$ and TNF- $\alpha-308 \mathrm{G} / \mathrm{A}$ gene polymorphisms (Heidari et al., 2014a, b, 2015b). Our observation showed that components of gingival connective tissue may be influenced by adverse effects of periodontitis and inflammatory cytokines more than epithelial cells (Heidari et al., 2014a, 2015b). A possible reason for the lack of significant difference in connective tissue $\mathrm{V} v_{v}$ between patients may be that each component of connective tissue is probably influenced differently by inflammatory cytokines (Heidari et al., 2014a, 2015b; Golijanin et al., 2015).

The present investigation showed that there were significant differences in volume of collagenous matrix in $\mathrm{CP}$ gingival samples IFN- $\gamma+874 \mathrm{~A} / \mathrm{T}$ gene polymorphism with TT, AT and AA genotypes. In agreement with these findings, our previous studies showed that there was a significant difference in the volume of collagenous matrix in CP samples with different genotypes of TGF- $\beta-509 \mathrm{C} / \mathrm{T}$ and $29 \mathrm{C} / \mathrm{T}$ gene polymorphisms (Heidari et al., 2014a, 2015b). Reports have showed that in severe cases of periodontitis, there were many macrophages around the fibers of collagenous matrix facilitating their breakdown. Biological products of macrophages play important role in the destruction of periodontal structures and other inflammatory cells activities (Golijanin et al., 2015). As regards, IFN- $\gamma$ is known as a macrophage activator factor (Holla et al., 2011) and TGF- $\beta 1$ is produced by these inflammatory cells (Heidari et al., 2015b). The difference of collagenous matrix volume in patients with different genotypes of these polymorphisms may result from the macrophage activities.

Our present investigation showed that there was significant difference in the volume of non-collagenous matrix in CP gingival samples with TT, AT and AA genotypes. We have previously shown that non-collagenous matrix was not 
significantly differenct between patient samples with TGF- $\beta-509$ C/T and 29 C/T gene polymorphisms (Heidari et al., 2015b). IFN- $\gamma$ is able to induce antigen expression on antigen-presenting cell surfaces (Wassenaar et al., 1997; Konermann et al., 2012) and probably is the reason for accumulation of inflammatory cells in gingival connective tissue that leads to the change of non-collagenous matrix.

Present results showed that blood vessels volume in gingival tissues was not significantly different between TT, AT and AA groups. In contrast, our previous studies showed that there were significant differences in the volume of blood vessels in CP samples with different genotypes of TGF- $\beta-509 \mathrm{C} / \mathrm{T}$ and $29 \mathrm{C} / \mathrm{T}$ gene polymorphisms (Heidari et al., 2014a, 2015b). Different results may be due to the regulatory role of TGF- $\beta$ in the angiogenesis (Heidari et al., 2015b).

All of these finding indicate that some cytokine gene polymorphisms are associated with the quantitative changes of periodontal structures during $\mathrm{CP}$ (Heidari, 2014). The incongruous results can be explained by the association of disease progression with interactive types of cytokines or genetic markers predisposing for the disease in the studied cases (Heidari et al., 2013; Heidari, 2014). It is indicated that for complex diseases such as periodontitis, the single effects of each genetic polymorphism on disease process is not substantial, and the interaction between various gene polymorphisms and between genes and environment possibly can impress the ascertained phenotypes (Laine et al., 2012). Meta-analyses of cumulative effects of cytokine polymorphisms and additional studies on other gene polymorphisms of IFN- $\gamma$, IFN- $\gamma$ receptors and gene expression are required to explore the role of cytokines in CP pathogenesis.

\section{Conclusion}

Result of the present study showed a significant difference in the quantitative parameters of connective tissue constituents of interdental gingiva between $\mathrm{CP}$ patients with different genotypes of IFN- $\gamma+874 \mathrm{~A} / \mathrm{T}$ polymorphism.

Acknowledgements: The authors thank to Zahedan University of Medical Sciences that funded this project and the participants who willingly cooperated in this study.

\section{References}

Armingohar, Z., Jørgensen, J., Kristoffersen, A., Schenck, K., Dembic, Z. (2014) Polymorphisms in the interleukin-1 gene locus and chronic periodontitis in patients with atherosclerotic and aortic aneurysmal vascular diseases. Scand. J. Immunol. 79, 338-345.

Armitage, G. C. (1999) Development of a classification system for periodontal diseases and conditions. Ann. Periodontol. 4, 1-6.

Armitage, G. C. (2004) Periodontal diagnoses and classification of periodontal diseases. Periodontol. 2000 34, 9-21.

Atilla, G., Emingil, G., Köse, T., Berdeli, A. (2006) TGF- $\beta 1$ gene polymorphisms in periodontal diseases. Clin. Biochem. 39, 929-934.

César-Neto, J. B., Duarte, P. M., De Oliveira, M. C. G., Casati, M. Z., Tambeli, C. H., Parada, C. A., Sallum, E. A., 
Nociti, F. H. (2006) Smoking modulates interferon- $\gamma$ expression in the gingival tissue of patients with chronic periodontitis. Eur. J. Oral Sci. 114, 403-408.

Chapple, C. C., Kumar, R. K., Hunter, N. (2000) Vascular remodelling in chronic inflammatory periodontal disease. J. Oral Pathol. Med. 29, 500-506.

Di Benedetto, A., Gigante, I., Colucci, S., Grano, M. (2013) Periodontal disease: Linking the primary inflammation to bone loss. Clin. Dev. Immunol. 2013, 503754.

Erciyas, K., Pehlivan, S., Sever, T., Igci, M., Arslan, A., Orbak, R. (2010) Association between TNF- $\alpha$, TGF- $\beta 1$, IL-10, IL-6 and IFN- $\gamma$ gene polymorphisms and generalized aggressive periodontitis. Clin. Invest. Med. 33, 85-91.

Genco, R. J., Borgnakke, W. S. (2013) Risk factors for periodontal disease. Periodontol. 2000 62, 59-94.

Golijanin, R., Kujundžić, B., Milosavljević, Z., Milovanović, D. R., Anđelković, Z., Obrenović, M., Nikolić, R. (2015) Morphometric analysis of collagen and inflammatory cells in periodontal disease. Vojnosanit. Pregl. 72, 219-224.

Heidari, Z. (2014) The association between proinflammatory gene polymorphisms and level of gingival tissue degradation in chronic periodontitis. Gene Cell Tissue 1, e21898.

Heidari, Z., Mahmoudzadeh-Sagheb, H., Rigi-Ladiz, M. A., Taheri, M., Moazenni-Roodi, A., Hashemi, M. (2013) Association of TGF- $\beta 1-509 \mathrm{C} / \mathrm{T}, 29 \mathrm{C} / \mathrm{T}$ and $788 \mathrm{C} / \mathrm{T}$ gene polymorphisms with chronic periodontitis: a case-control study. Gene 518, 330-334.

Heidari, Z., Mahmoudzadeh-Sagheb, H., Hashemi, M., Rigi-Ladiz, M.A. (2014a) Quantitative analysis of interdental gingiva in patients with chronic periodontitis and transforming growth factor- $\beta 129 \mathrm{C} / \mathrm{T}$ gene polymorphisms. J. Periodontol. 85, 281-289.

Heidari, Z., Mahmoudzadeh-Sagheb, H., Hashemi, M., Rigi-Ladiz, M. A. (2014b) Stereological analysis of interdental gingiva in chronic periodontitis patients with tumor necrosis factor-alpha (-308 G/A) gene polymorphisms. Gene Cell Tissue 1, e18315.

Heidari, Z., Mahmoudzadeh-Sagheb, H., Hashemi, M., Ansarimoghaddam, S., Moudi, B., Sheibak, N. (2015a) Association between IFN- $\gamma+874 \mathrm{~A} / \mathrm{T}$ and IFN- $\gamma \mathrm{R} 1$ (-611A/G, +189T/G, and +95C/T) gene polymorphisms and chronic periodontitis in a sample of Iranian population. Int. J. Dent. 2015, 375359.

Heidari, Z., Sagheb, H. M., Sheibak, N. (2015b) Association between TGF-beta1 (-509) C/T gene polymorphism and tissue degradation level in chronic periodontitis: a stereological study. Gene Cell Tissue 2, e31698.

Holla, L. I., Hrdlickova, B., Linhartova, P., Fassmann, A. (2011) Interferon- $\gamma+874 \mathrm{~A} / \mathrm{T}$ polymorphism in relation to generalized chronic periodontitis and the presence of periodontopathic bacteria. Arch. Oral Biol. 56, 153-158.

Irwin, C., Myrillas, T. (1998) The role of IL-6 in the pathogenesis of periodontal disease. Oral Dis. 4, 43-47.

Kim, J., Amar, S. (2006) Periodontal disease and systemic conditions: a bidirectional relationship. Odontology 94, 10-21.

Konermann, A., Deschner, J., Allam, J., Novak, N., Winter, J., Baader, S., Jepsen, S., Jäger, A. (2012) Antigenpresenting cell marker expression and phagocytotic activity in periodontal ligament cells. J. Oral Pathol. Med. 41, 340-347.

Laine, M. L., Crielaard,W., Loos, B. G. (2012) Genetic susceptibility to periodontitis. Periodontol. 200058 , 37-68.

Liu, N., Song, Y., Shi, W. (2015) IFN- $\gamma+874$ T/A polymorphisms contributes to cervical cancer susceptibility: a meta-analysis. Int. J. Clin. Exp. Med. 8, 4008-4015.

Loos, B. G., John, R. P., Laine, M. L. (2005) Identification of genetic risk factors for periodontitis and possible mechanisms of action. J. Clin. Periodontol. 32, 159-179.

Ohlrich, E., Cullinan, M., Seymour, G. (2009) The immunopathogenesis of periodontal disease. Aust. Dent. J. 54, S2-S10. 
Okada, H., Murakami, S. (1998) Cytokine expression in periodontal health and disease. Crit. Rev. Oral Biol. Med. 9, 248-266.

Pacheco, A. G., Cardoso, C. C., Moraes, M. O. (2008) IFNG +874T/A, IL10-1082G/A and TNF -308G/A polymorphisms in association with tuberculosis susceptibility: a meta-analysis study. Hum. Genet. 123, 477-484.

Pinchback, J. S., Taylor, B. A., Gibbins, J. R., Hunter, N. (1996) Microvascular angiopathy in advanced periodontal disease. J. Pathol. 179, 204-209.

Pravica, V., Perrey, C., Stevens, A., Lee, J.-H., Hutchinson, I.V. (2000) A single nucleotide polymorphism in the first intron of the human IFN- $\gamma$ gene: Absolute correlation with a polymorphic CA microsatellite marker of high IFN- $\gamma$ production. Hum. Immunol. 61, 863-866.

Preethi, P. L., Rao, S. R., Madapusi, B. T., Narasimhan, M. (2014) Immunolocalization of Ki-67 in different periodontal conditions. J. Indian Soc. Periodontol. 18, 161-165.

Séguier, S., Godeau, G., Brousse, N. (2000a) Immunohistological and morphometric analysis of intra-epithelial lymphocytes and Langerhans cells in healthy and diseased human gingival tissues. Arch. Oral Biol. 45, $441-452$.

Séguier, S., Godeau, G., Leborgne, M., Pivert, G., Brousse, N. (2000b) Quantitative morphological analysis of Langerhans cells in healthy and diseased human gingiva. Arch. Oral Biol. 45, 1073-1081.

Stabholz, A., Soskolne, W. A., Shapira, L. (2010) Genetic and environmental risk factors for chronic periodontitis and aggressive periodontitis. Periodontol. 2000 53, 138-153.

Tanaka, M. H., Giro, E. M., Cavalcante, L. B., Pires, J. R., Apponi, L. H., Valentini, S. R., Spolidório, D. M., Capela, M.V., Rossa, C. Jr., Scarel-Caminaga, R. M. (2012) Expression of interferon- $\gamma$, interferon- $\alpha$ and related genes in individuals with Down syndrome and periodontitis. Cytokine 60, 875-881.

Wassenaar, A., Snijders, A., Abraham-Inpijn, L., Kapsenberg, M., Kievits, F. (1997) Antigen-presenting properties of gingival fibroblasts in chronic adult periodontitis. Clin. Exp. Immunol. 110, 277-284.

Younes, R., Ghorra, C., Khalife, S., Igondjo-Tchen-Changotade, S., Yousfi, M., Willig, C., Senni, K., Godeau, G., Naaman, N. (2009) Pertinent cell population to characterize periodontal disease. Tissue Cell 41, 141-150.

Zhang, S., Crivello, A., Offenbacher, S., Moretti, A., Paquette, D. W., Barros, S. P. (2010) Interferon-gamma promoter hypomethylation and increased expression in chronic periodontitis. J. Clin. Periodontol. 37, 953-961.

Zoellner, H., Chapple, C. C., Hunter, N. (2002) Microvasculature in gingivitis and chronic periodontitis: Disruption of vascular networks with protracted inflammation. Microsc. Res. Tech. 56, 15-31.

Sheibak N.; Heidari Z.; Mahmoudzadeh-Sagheb H. 